\title{
INFLUENCE OF MICROARC OXIDATION MODES ON THE STRUCTURE, GROWTH KINETICS, PHASE COMPOSITION AND HARDNESS OF OXIDE COATINGS FORMED ON THE AK6 ALUMINUM ALLOY
}

\section{ВПЛИВ РЕЖИМІВ МІКРОДУГОВОГО ОКСИДУВАННЯ НА СТРУКТУРУ, КІНЕТИКУ ЗРОСТАННЯ, ФАЗОВИЙ СКЛАД І ТВЕРДІСТЬ ОКСИДНИХ ПОКРИТТІВ, ЯКІ ФОРМУЮТЬСЯ НА АЛЮМІНІЕВОМУ СПЛАВІ АКб}

\author{
Valeriia V. Subbotina \\ subbotina.valeri@gmail.com \\ ORCID: 0000-0002-3882-0368
}

\section{В. В. Субботіна,}

канд. техн. наук

\author{
National Technical University “Kharkov Polytechnic Institute”, Kharkiv \\ Національний технічний університет «Харківський політехнічний інститут», м. Харків
}

\begin{abstract}
In recent years, the industrial use of the micro-arc oxidation method has been actively developing to obtain hard and wear-resistant layers on the surface of products made of aluminum alloys. The formation of oxide coatings by the microarc method takes place under conditions of ultrafast thermalization and is determined by a set of various processes associated with different elemental composition of alloys and electrolysis conditions. Therefore, the aim of the study was to study the effect of the technological conditions of oxidation (electrolyte composition, current density, process duration) of the AK6 alloy (Al-Cu-Si-Mg system) on the structure, growth kinetics, phase composition, and hardness of the formed oxide coatings. To solve this goal were carried out: metallographic, X-ray diffraction analysis, measurement of coating thickness and microhardness. It was found that the coatings formed on the AK6 alloy as a result of microarc oxidation have a two-layer structure of a surface technological layer and an inner base layer. The technological layer thickness is $30-40 \%$ of the total coating thickness. The main phase of the technological layer is a phase with a relatively low hardness - mullite $\left(3 \mathrm{Al}_{2} \mathrm{O}_{3} \cdot 2 \mathrm{SiO}_{2}\right)$. The main phases of the base layer are oxide phases of high hardness $\gamma-\mathrm{Al}_{2} \mathrm{O}_{3}$ and $\alpha-\mathrm{Al}_{2} \mathrm{O}_{3}$ (corundum). It was determined that the current density affects both the growth rate of the coating and the phase composition in it. At low current density and short process times (up to $30 \mathrm{~min}$ ), microarc oxidation of the AK6 alloy does not provide the formation of the $\alpha-\mathrm{Al}_{2} \mathrm{O}_{3}$ phase, and the main phase is $\gamma-\mathrm{Al}_{2} \mathrm{O}_{3}$. This does not allow reaching a high hardness of the coating, which is less than $15000 \mathrm{MPa}$. An increase in the current density from 10 to $25 \mathrm{~A} / \mathrm{dm}^{2}$ leads to an almost twofold increase in the coating growth rate, while the phase composition of the coatings changes from a two-phase composition based on $\gamma-\mathrm{Al}_{2} \mathrm{O}_{3}$ and mullite to a two-phase composition based on $\alpha-\mathrm{Al}_{2} \mathrm{O}_{3}$ and $\gamma-\mathrm{Al}_{2} \mathrm{O}_{3}$ phases. The composition of the alkali-silicate electrolyte affects the growth rate and phase composition: with an increase in the content of the silicate $\left(\mathrm{Na}_{2} \mathrm{SiO}_{3}\right)$ component in the alkali-silicate electrolyte, the growth rate of the coating increases, but the phase composition is enriched with a mullite phase with low hardness. The highest hardness of $18200 \mathrm{MPa}$ is achieved in the $\mathrm{KOH}-1 \mathrm{~g} / \mathrm{L}+\mathrm{Na}_{2} \mathrm{SiO}_{3}-6 \mathrm{~g} / \mathrm{L}$ electrolyte with the longest electrolysis process duration of $300 \mathrm{~min}$, when a coating is formed with a base layer thickness of about $150 \mu \mathrm{m}$ in which the content of the $\alpha-\mathrm{Al}_{2} \mathrm{O}_{3}$ phase reaches $87 \%$.
\end{abstract}

Key words: microarc oxidation; electrolyte composition; AK6 alloy; coating; thickness; phase composition; hardness.

Анотація. В останні роки активно розвивається промислове використання методу мікродугового оксидування для отримання твердих і зносостійких шарів на поверхні виробів з алюмінієвих сплавів. Формування оксидних покриттів мікродуговим методом проходить в умовах надшвидкого термалізування і визначається сукупністю різноманітних процесів, пов'язаних із різним елементним складом сплавів і умовами електролізу. Тому метою дослідження було вивчення впливу технологічних умов оксидування (склад електроліту, щільність струму, тривалість процесу) сплаву АК6 (система Al-Cu-Si-Mg) на структуру, кінетику зростання, фазовий склад і твердість сформованих оксидних покриттів. Для досягнення поставленої мети були проведені металографічний, рентгеноструктурний аналіз, вимірювання товщини покриття та мікротвердості. Встановлено, що покриття, сформовані на сплаві АК6 у результаті мікродугового оксидування, мають двошарову структуру, яка складається з поверхневого технологічного шару і внутрішнього базового шару. Товщина технологічного шару становить $30-40 \%$ від загальної товщини покриття. Основною фазою технологічного 
шару є фаза з відносно низькою твердістю - муліт $\left(3 \mathrm{Al}_{2} \mathrm{O}_{3} \cdot 2 \mathrm{SiO}_{2}\right)$. Основними фазами базового шару є оксидні фази високої твердості $\gamma-\mathrm{Al}_{2} \mathrm{O}_{3} \mathrm{i} \alpha-\mathrm{Al}_{2} \mathrm{O}_{3}$ (корунд). Визначено, що щільність струму впливає на швидкість зростання покриття і на фазовий склад у ньому. За низької щільності струму і тривалості процесу (до 30 хвилин) мікродугове оксидування сплаву АК6 не забезпечує утворювання фази $\alpha-\mathrm{Al}_{2} \mathrm{O}_{3}$, а основною фазою $\epsilon \gamma-\mathrm{Al}_{2} \mathrm{O}_{3}$. Це не дозволяє досягнути великої твердості покриття, яка становить менше 15000 МПа. Збільшення щільності

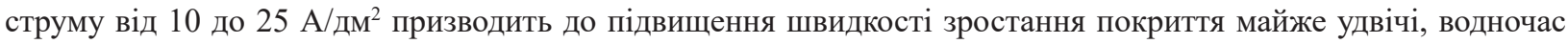
фазовий склад покриттів змінюється від двофазного на основі $\gamma-\mathrm{Al}_{2} \mathrm{O}_{3}$ i муліту на двофазний на основі $\alpha-\mathrm{Al}_{2} \mathrm{O}_{3}$ i $\gamma-\mathrm{Al}_{2} \mathrm{O}_{3}$ фаз. Склад лужно-силікатного електроліту впливає на швидкість зростання і фазовий склад: у разі збільшення вмісту силікатної $\left(\mathrm{Na}_{2} \mathrm{SiO}_{3}\right)$ складової частини в лужно-силікатному електроліті підвищується швидкість зростання покриття, проте фазовий склад збагачується мулітною фазою з невисокою твердістю. Найбільш висока твердість 18200 МПа досягається в електроліті $\mathrm{KOH}-1$ г/л $+\mathrm{Na}_{2} \mathrm{SiO}_{3}-6$ г/л за максимальної тривалості процесу електролізу 300 хвилин, коли формується покриття 3 товщиною базового шару приблизно 150 мкм, у якому вміст $\alpha-\mathrm{Al}_{2} \mathrm{O}_{3}$ фази досягає $87 \%$.

Ключові слова: мікродугове оксидування; склад електроліту; сплав АК6; покриття; товщина; фазовий склад; твердість.

\section{ПОСТАНОВКА ЗАДАЧІ}

Метод мікродугового оксидування (далі - МДО) дозволяє формувати на поверхні алюмінієвих сплавів покриття із широким спектром фізико-механічних властивостей та структур. МДО знаходить все більш широке застосування для формування на вентильних металах захисних, декоративних i функціональних покриттів.

Можливість одночасного отримання високих значень зносостійкості, корозійної тривкості, адгезії й інших експлуатаційних характеристик під час створення нових функціональних покриттів визначає актуальність вирішення задач, пов'язаних із вивченням закономірностей формування МДО-покриттів із заданими властивостями на алюмінієвих сплавах.

Робота присвячена вивченню закономірності формування зміцнених поверхневих шарів методом саме мікродугового оксидування на алюмінієвому сплаві АК6.

\section{АНАЛІЗ ОСТАННІХ ДОСЛІДЖЕНЬ І ПУБЛІКАЦІЙ}

Успішне вирішення технічних завдань вимагає впровадження прогресивних технологій, що забезпечують якість випущених машин, обладнання та приладів, підвищення їхнього технічного рівня. Одним 3 істотних чинників підвищення якості та надійності виробів машинобудування стає зниження зносу і збільшення довговічності вузлів тертя.

У зв'язку із цим в останні роки активно розвивається зміцнення поверхні деталей методом мікродугового оксидування [1-3]. За своєю зносостійкістю оксидні покриття, отримані методом мікродугового оксидування (МДО) на алюмінієвих сплавах, у 10-15 разів перевершують анодні [4], вони набагато міцніше інших типів покриттів за корозійною тривкістю [5]. Нанесенням МДО покриттів на поверхні деталей, що труться, вдається значно знизити коефіцієнт тертя [6].

Для алюмінієвих сплавів такі покриття є основою багатьох технологій $[7 ; 8]$. До числа таких алюмініє- вих сплавів, деталі з яких доцільно обробляти мікродуговим оксидуванням, належить сплав АК6, який схильний до корозії під напругою і чутливий до міжкристалітної корозії [9].

Необхідно відзначити, що формування оксидних покриттів мікродуговим методом визначається сукупністю різноманітних процесів, тому якість покриттів залежить від багатьох чинників [10; 11]. Серед цих чинників найбільше впливають хімічний склад оксидуємого сплаву, склад електроліту і режим МДО [12-14].

Отже, розроблення технології зміцнення конкретного алюмінієвого сплаву АК6, із властивим йому складом легуючих елементів, потребує комплексу дослідницьких робіт.

\section{ВІДОКРЕМЛЕННЯ НЕ ВИРІШЕНИХ} РАНІШЕ ЧАСТИН ЗАГАЛЬНОЇ ПРОБЛЕМИ

Нині недостатньо даних для уявлення про характер впливу умов електролізу (складу електроліту, часу оброблення) на механізм і кінетику утворювання покриттів на сплаві АК6 методом мікродугового оксидування. А без розуміння цього спрямована зміна структурного стану і властивостей МДО покриттів неможлива.

\section{МЕТА ДОСЛІДЖЕННЯ}

Метою роботи було вивчення впливу технологічних умов формування (щільність струму, тривалість оксидування) у лужно-силікатних електролітах різного складу оксидного покриття на алюмінієвому сплаві АК6 на його структуру, кінетику зростання, фазовий склад і твердість.

\section{МЕТОДИ, ОБ'ЄКТ ТА ПРЕДМЕТ ДОСЛІДЖЕННЯ}

Матеріалом досліджень служив алюмінієвий сплав АК6. Його хімічний склад наведено в таблиці 1.

Для мікродугового оксидування використовувалися зразки зі сплаву АК6 у вигляді шайб, діаметром 50 мм і товщиною 10 мм. Електроконтакт зі зразком під час МДО-процесу забезпечувався за допомогою нарізного з'єднання. 
Таблиця 1. Хімічний склад (у мас. \%) сплаву АК6 (ГОСТ 4784-97)

\begin{tabular}{|c|c|c|c|c|c|c|c|c|}
\hline $\mathrm{Fe}$ & $\mathrm{Si}$ & $\mathrm{Mn}$ & $\mathrm{Ni}$ & $\mathrm{Ti}$ & $\mathrm{Al}$ & $\mathrm{Cu}$ & $\mathrm{Mg}$ & $\mathrm{Zn}$ \\
\hline до 0,7 & $0,7-1,2$ & $0,4-0,8$ & до 0,1 & до 0,1 & $93,3-96,7$ & $1,8-2,6$ & $0,4-0,8$ & до 0,3 \\
\hline
\end{tabular}

Мікродугове оксидування проводилося у ванні об'ємом 100 літрів, в анодно-катодному режимі [15]. Під час МДО-процесу забезпечувалися охолоджування і барботування електроліту. Середнє значення напруги становило 380 В. Щільність струму становила 10, 15, 20, 25, 40 i $60 \mathrm{~A} /$ дм² $^{2}$ У процесі оксидування температура електроліту не перевищувала $40{ }^{\circ} \mathrm{C}$, яка підтримувалося інтенсивним перемішуванням електроліту стисненим повітрям і охолоджуванням ванни проточною водою. Тривалість оксидування варіювалася від 30 до 300 хвилин.

Процес мікродугового оксидування здійснювався в лужно-силікатних електролітах за початкових $\mathrm{pH}=$ $10,0-13,0$ і $\rho=100-350$ Ом/см. Типи і характеристики електролітів, що застосовуються для оптимізації технології нанесення МДО-покриттів на сплаві АК6, наведені в табл. 2.

Визначення фазового складу МДО-покриттів здійснювалося за результатами рентгенофазового аналізу. Дослідження проводилися на установці ДРОН3 (Буревісник, Росія) у монохроматизованому випромінюванні $\mathrm{K} \alpha-\mathrm{Cr}$. Випромінювання з великою довжиною хвилі $(\mathrm{K} \alpha-\mathrm{Cr})$ використовувалося для зменшення товщини інформативного шару. Дифракційні спектри знімалися за схемою Брегга-Брентано на відображення [16]. Знімання здійснювалася як у безперервному, так і в поточковому режимах, із кроком $2 \theta=0,1^{\circ}$.

Таблиця 2. Типи та характеристики електролітів, використаних під час мікродугового оксидування

\begin{tabular}{|c|c|c|c|c|}
\hline \multirow{2}{*}{ № } & \multicolumn{2}{|c|}{ Склад електроліту, г/л } & \multirow{2}{*}{$\mathbf{p H}$} & \multirow{2}{*}{$\boldsymbol{\rho}, \mathbf{O м} / \mathbf{c m}$} \\
\cline { 2 - 3 } & $\mathbf{K O H}$ & $\mathbf{N a}_{2} \mathbf{S i O}_{3}$ & & \\
\hline 1 & 1 & 6 & 11,60 & 254 \\
\hline 2 & 2 & 6 & 12,14 & 130 \\
\hline 3 & 2 & 12 & 11,9 & 150 \\
\hline
\end{tabular}

Для проведення кількісного фазового аналізу використовувався метод еталонних сумішей [17]. Для цього були побудовані градуювальні графіки залежності інтенсивностей ліній порівняння від складу суміші. Як базові складники складу покриттів використовувалися $\alpha-\mathrm{Al}_{2} \mathrm{O}_{3}$ (ASTM Card File 10-173), $\gamma-\mathrm{Al}_{2} \mathrm{O}_{3}$ (ASTM Card File 10-425) і муліт $\left(3 \mathrm{Al}_{2} \mathrm{O}_{3} \cdot 2 \mathrm{SiO}_{2}\right.$, ASTM Card File 15-776). У разі появи на дифракційних спектрах піків від алюмінієвої підкладки під час розрахунку складу покриття вони не враховувалися.

Дослідження морфології поверхні і бічного перетину покриттів проводилося методом растрової електронної мікроскопії на установці РЕМ МА 101 (BAT “SELMI", Україна). Для аналізу шорсткості поверхні використовувався топографічний контраст, заснований на тому, що відображення електронів і вторинна електронна емісія залежать від кута падіння пучка на зразок. Кут падіння змінювався через нерівності (топографіі) зразка, спричиняв утворювання контрасту, пов'язаного 3 формою об'єкта.

Визначення мікротвердості проводили на приладі ПМТ-3.

Випробування на мікротвердість проводилося за методом відновленого відбитка за навантаження 0,98$1,96 \mathrm{H}$.

Товщину оксидного шару на зразках вимірювали на поперечних шліфах металографічно і за допомогою вихрового товщиноміра ВТ-10НЦ.

\section{ОБГОВОРЕННЯ ОТРИМАНИХ РЕЗУЛЬТАТІВ}

Під час візуального спостереження за процесом оксидування у використовуваних електролітах було виявлено, що область мікродугових розрядів $є$ перехідною, з підвищенням напруги між електродом і зразком переходить у дугову. Цей процес можна трактувати так: характерною особливістю мікродугових розрядів $\epsilon$ поділ основного токопровідного каналу на безліч мікроканалів, які безперервно переміщаються поверхнею оксидної плівки. За високої температури в мікродугових каналах відбувається інтенсивне окиснення металу й ущільнення в результаті такого процесу пористих ділянок оксидного покриття. Подальше ущільнення і збільшення товщини оксидного покриття призводить до припинення мікророзрядів на цій ділянці і переміщення плазмового розряду до інших (більш тонких і пористих) ділянок покриття. Отже, мікродугові розряди переміщаються по всій поверхні (ніби заліковують тонкі та пористі ділянки покриття), що в результаті призводить до підвищення його електричних і механічних характеристик. Установлено, що в разі малої рухливості розряду на ділянці та посилення його потужності (виявлялося за збільшенням інтенсивності світіння) відбувалося плавлення покриття й утворювання кратерів аж до металу.

Вивчення структуроутворювання оксидних шарів у процесі їх зростання на сплаві АК6 проводилося за різних режимів мікродугового оксидування.

Однією з мікроструктурних особливостей оксидних покриттів, що формуються в режимі анодно-катодного мікродугового оксидування, $є$ їхня двошарова будова. Верхній шар покриття (пористий, з великою шорсткістю, з низькою адгезією, незносостійкий) легко видаляється шляхом зачищання на абразивному папері. Основу цього шару, за даними рентгеноструктурного аналізу, становить кристалічна фаза муліт $-3 \mathrm{Al}_{2} \mathrm{O}_{3} \cdot 2 \mathrm{SiO}_{2}$ (рис 1 a). Внутрішній шар покриття $\epsilon$ базовим шаром, що визначає властивості покриття. За рентгеноструктурними даними цей шар також кристалічний, проте його фазо- 
вий склад зовсім інший: це найбільш тверді оксидні фази алюмінію $\alpha-\mathrm{Al}_{2} \mathrm{O}_{3}$ (корунд) і $\gamma-\mathrm{Al}_{2} \mathrm{O}_{3}$ (рис. 1 б).

Двошарова будова оксидного покриття добре проявляється металографічно на поперечних шліфах. Товщина технологічного шару становить $30-40 \%$ від товщини базового (робочого) шару. Вид границі розділу «сплав АК6-оксид» (відсутність пор, включень, відшарувань) свідчить про хорошу адгезію покриття з основою (рис. 2).

Оскільки одним з основних технологічних параметрів за мікродугового оксидування є щільність струму, то в роботі для електролізу в розчині 1 г/л КОН + 6 г/л $\mathrm{Na}_{2} \mathrm{SiO}_{3}$ було досліджено вплив щільності струму на кінетику зростання і фазовий склад оксидного покриття, яке формувалося.

На рисунку 3 наведені результати впливу щільності струму на товщину оксидних покриттів, отриманих в електроліті $\mathrm{KOH}-1$ г/л $+\mathrm{Na}_{2} \mathrm{SiO}_{3}-6$ г/л. Відзначимо, як показали попередні візуальні дослідження, за малих щільностей струму (менше $5 \mathrm{~A} /$ дм²$^{2}$ ) процес протікає на сплаві АК6 у режимі іскріння. базовий шар не формується. За великої щільності струму (понад 50 А/дм²) процес більш швидкий (менш ніж за 10 хвилин), переходить у режим дугових розрядів, такі покриття втрачають свою суцільність у результаті формування пробоїв до основного металу.

Із представлених на рисунку 3 результатів видно, що збільшення щільності струму призводить до більшої товщині покриттів за однакового часу оксидування. Оцінка швидкості зростання загальної товщини покриття від часу оксидування за найменшої щільності струму $\left(\mathrm{j}=10 \mathrm{~A} /\right.$ дм² $\left.^{2}\right)$ становить 0,46 мкм/хв, а базового шару - 0,24 мкм/хв. У разі збільшення щільності струму до $\mathrm{j}=15 \mathrm{~A} /$ дм $^{2}$ швидкість зростання загальної товщини покриття збільшилася до 0,5 мкм/хв, а базового шару $-0,35$ мкм/хв. Значне збільшення швидкості зростання спостерігалося в разі збільшення щільності струму до $\mathrm{j}=25 \mathrm{~A} /$ дм² $^{2}$. Для такого технологічного режиму загальна швидкість зростання покриття збільшилася до 0,68 мкм/хв, а швидкість зростання базового шару становила 0,43 мкм/хв.

За більшої щільності струму 40 і 60 А/дм² швидкість зростання збільшувалася тільки на початковій стадії процесу окиснення (до 120 хв). Для цієї стадії окиснення швидкість становила 0,91 мкм /хв (базового шару $-0,58$ мкм/хв) за ј $=40 \mathrm{~A} /$ дм $^{2}, 1,04$ мкм/хв (базового шару $-0,50$ мкм/хв) за $\mathrm{j}=60 \mathrm{~A} /$ дм² $^{2}$.

Однакзавеликоїтривалості(180-300хв)великащільність струму не $є$ оптимальною з погляду швидкості зростання, імовірно, через вплив процесу розтравлювання, атакож можливий перехіду дуговий режим. $3 a \mathrm{j}=40 \mathrm{~A} /$ дм $^{2}$ швидкість зростання зменшується до 0,71 мкм/хв (базового шару - 0,40 мкм/хв), а за $\mathrm{j}=60 \mathrm{~A} /$ дм$^{2}$ швидкість зростання зменшилася до 0,72 мкм/хв (базового шару - 0,35 мкм/ хв).

Хоча зі збільшенням щільності струму кінетичні параметри процесу зростають, важливим чинником є формований водночас фазовий склад. На рисунку 4 представлені залежності фазового складу від часу оксидування для різної щільності струму за МДО-процесу.
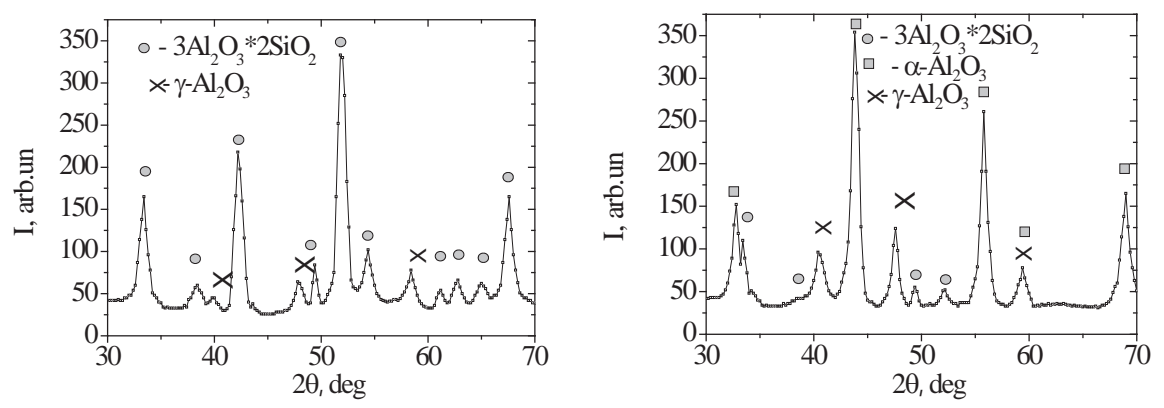

Рис. 1. Ділянки дифракційних спектрів МДО-покриття, отриманого в електроліті 1 г/л $\mathrm{KOH}+6$ г/л $\mathrm{Na}_{2} \mathrm{SiO}_{3}(180$ хв): a - верхній технічний шар; б - базовий шар покриття
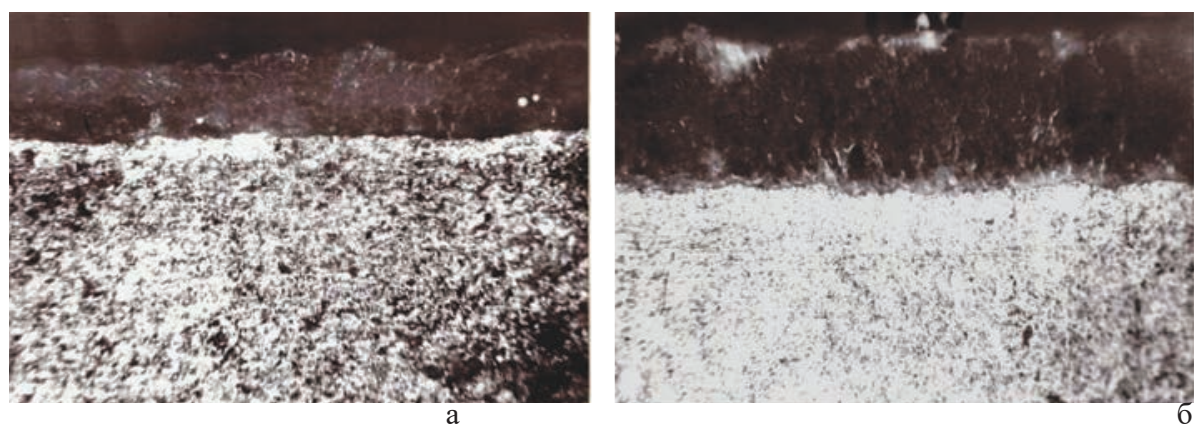

Рис. 2. Мікроструктура сплаву АК6 з оксидним покриттям: а - електроліт 1 г/л КОН + 6 г/л $\mathrm{Na}_{2} \mathrm{SiO}_{3}\left(\tau=180\right.$ мин, j= $25 \mathrm{~A} /$ дм$\left.^{2}\right) ; \sigma-2$ г/л КОН +12 г/л $\mathrm{Na}_{2} \mathrm{SiO}_{3}(\tau=180$ мин, $\left.\mathrm{j}=25 \mathrm{~A} / \mathrm{дм}^{2}\right)$ 

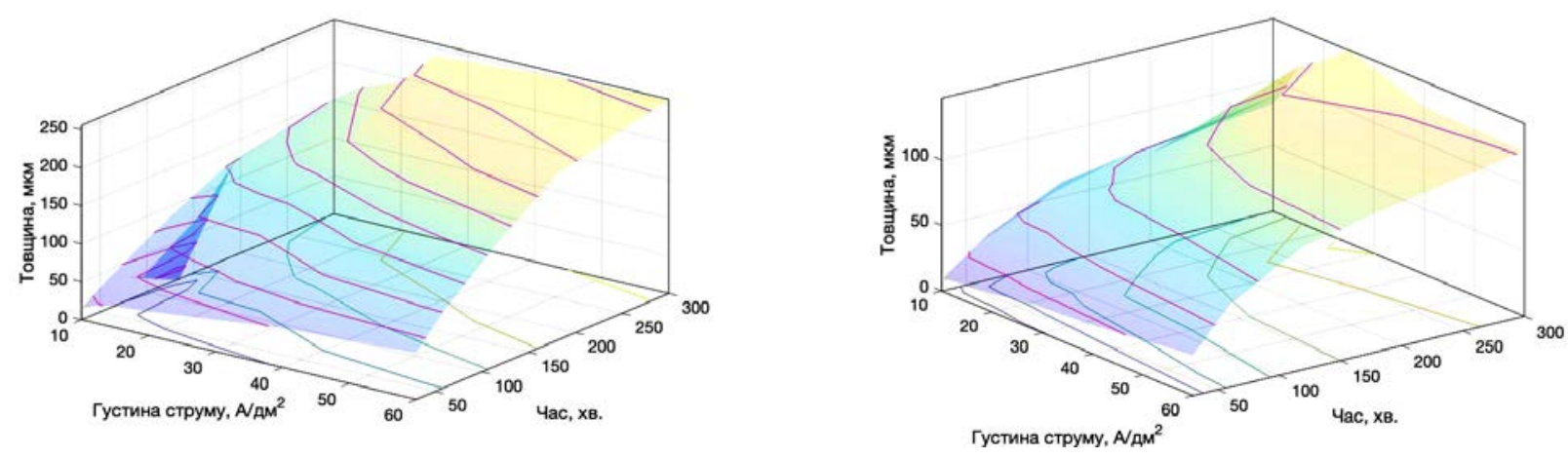

a

б

Рис. 3. Вплив щільності струму і тривалості оксидування на загальну товщину покриттів (а) і товщина базового шару (б) на алюмінієвому сплаві АК6 (електроліт $\mathrm{KOH}-1$ г/л $+\mathrm{Na}_{2} \mathrm{SiO}_{3}-6$ г/л)

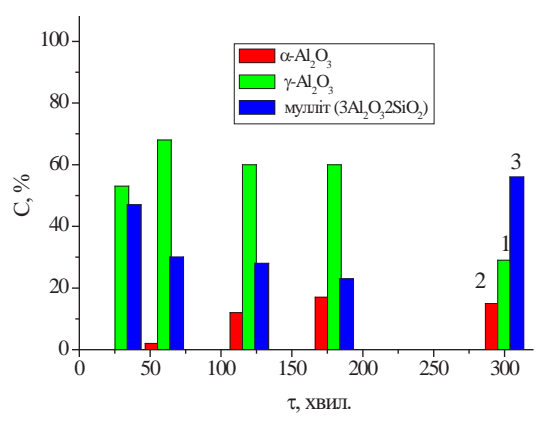

a

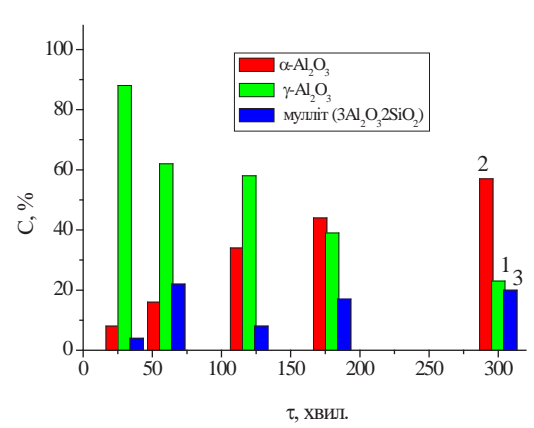

B

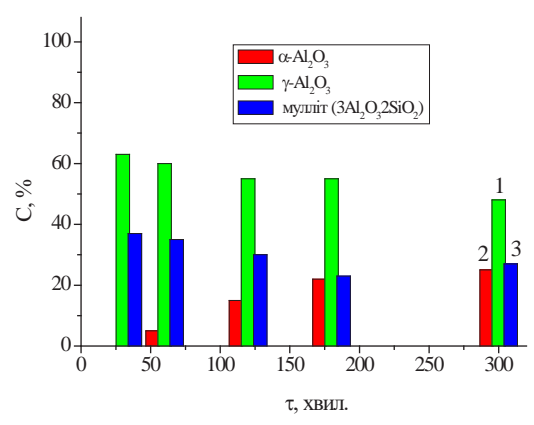

6

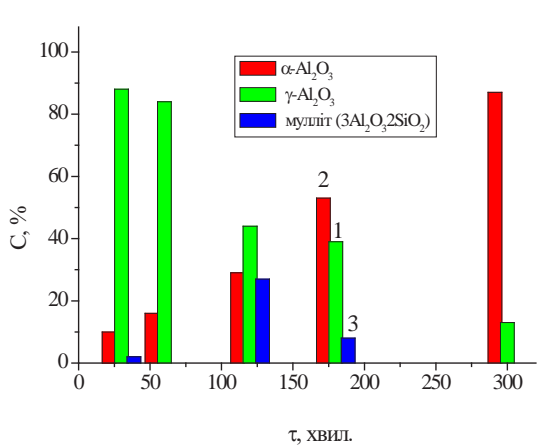

$\Gamma$

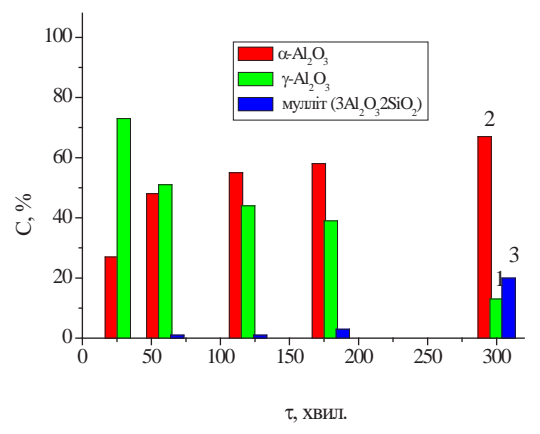

Д

Рис. 4. Залежність фазового складу від часу оброблення оксидування зарізноїщільності струму: а-10 A/дм²; б- $15 \mathrm{~A} /$ дм$^{2} ;$ в $-20 \mathrm{~A} /$ дм$^{2} ;$ г $-25 \mathrm{~A} /$ дм$^{2} ;$ д $-40 \mathrm{~A} /$ дм$^{2} .1-\gamma-\mathrm{Al}_{2} \mathrm{O}_{3} ; 2-\alpha-\mathrm{Al}_{2} \mathrm{O}_{3} ; 3$ - муліт $\left(3 \mathrm{Al}_{2} \mathrm{O}_{3} \cdot 2 \mathrm{SiO}_{2}\right)$ 
Також залежно від щільності струму був вивчений фазовий склад покриттів.

Результати, наведені на рис. 4, показують, що збільшення щільності струму за малої тривалості МДОпроцесу (до 60 хв) призводять до збільшення відносного вмісту в покритті фаз $\alpha-\mathrm{Al}_{2} \mathrm{O}_{3}$ i $\gamma-\mathrm{Al}_{2} \mathrm{O}_{3} \mathrm{i}$ зменшення мулітної складової частини. Однак у разі тривалого процесу оксидування (більше 180 хв) велика щільність струму (40 А/дм²) призводить до появи у складі покриття мулітної складової частини, імовірно, через процеси перегрівання під час переходу в дуговий режим.

Отримані результати свідчать, що найбільш ефективні режими оксидування сплаву АК6 за використання щільності струму $25 \mathrm{~A} /$ дм² $^{2}$, коли формується двофазний стан із найбільш твердих оксидних фаз $\alpha-\mathrm{Al}_{2} \mathrm{O}_{3} \mathrm{i} \gamma-\mathrm{Al}_{2} \mathrm{O}_{3}$. Крім того, збільшення щільності потоку вище $25 \mathrm{~A} /$ дм $^{2}$ недоцільно, оскільки відносне збільшення водночас товщини базового шару невелике, а енерговитрати зростають, що знижує ефективність процесу.

Тому подальші дослідження були проведені під час електролізу зі струмовим режимом, що забезпечує щільності струму $25 \mathrm{~A} /$ дм² $^{2}$

Кінетика зростання покриття і зміна розміру зразка для покриттів, отриманих за $\mathrm{j}=25 \mathrm{~A} /$ дм² $^{2}$ за різного складу електроліту, наведена на рисунку 5. Видно, що зі збільшенням відносного вмісту силікатної складової частини ( $\left.\mathrm{Na}_{2} \mathrm{SiO} 3\right)$ збільшується швидкість зростання покриття, проте зменшується відносне відношення базового шару до загальної товщині покриття.

За абсолютним значенням швидкість зміни загальної товщини покриття, за даними рисунка 5а, змінюється на лінійній залежності (яка спостерігається до 150 хв процесу) від 0,9 мкм/хв (для покриттів, отриманих в електроліті $\mathrm{KOH}-1$ г/л $+\mathrm{Na}_{2} \mathrm{SiO}_{3}-6$ г/л) i 0,72 мкм/хв (для покриттів, отриманих в електроліті $\mathrm{KOH}-2$ г/л $+\mathrm{Na}_{2} \mathrm{SiO}_{3}-6$ г/л) до 1,33 мкм/хв (для покриттів, отриманих в електроліті $\mathrm{KOH}-2$ г/л + $\mathrm{Na}_{2} \mathrm{SiO}_{3}-12$ г/л).

Зміна товщини базового шару має меншу швидкість. За абсолютним значенням така зміна, за даними рисунка 5б, становить 0,55 мкм/хв (для покриттів, отриманих в електроліті $\mathrm{KOH}-1$ г/л $+\mathrm{Na}_{2} \mathrm{SiO}_{3}-$ 6 г/л), 0,50 мкм/хв (для покриттів, отриманих в електроліті $\mathrm{KOH}-2$ г/л $+\mathrm{Na}_{2} \mathrm{SiO}_{3}-6$ г/л) і 0,75 мкм/хв (для покриттів, отриманих в електроліті $\mathrm{KOH}-2$ г/л $+\mathrm{Na}_{2} \mathrm{SiO}_{3}-12$ г/л).

На рисунку 5в показана залежність прирощування загальної товщини зразка (визначалася шляхом мікрометричних змін зразка до і після оксидування)

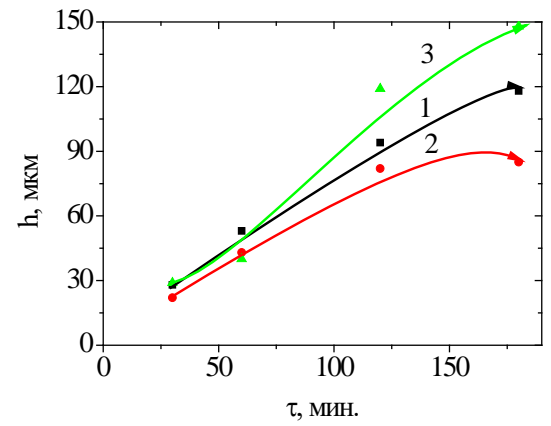

б

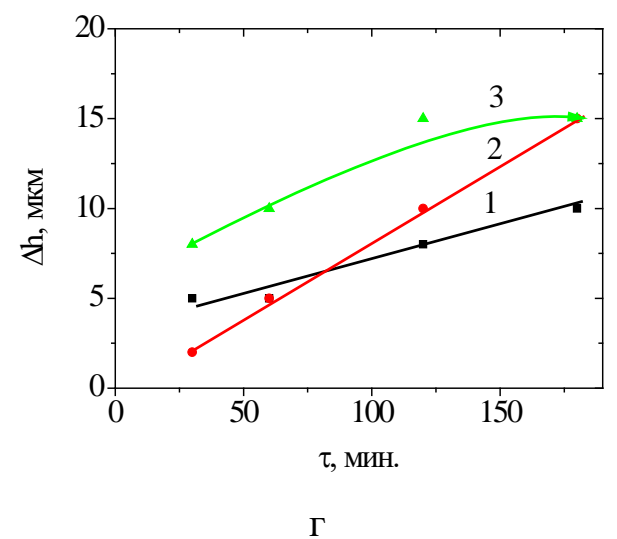

Рис. 5. Залежність (а) загальної товщини, (б) базової товщини і (в) прирощування

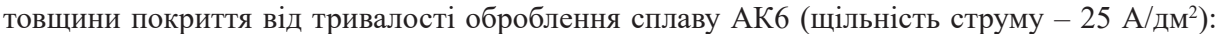
1 - електроліт $\mathrm{KOH}-1$ г/л $+\mathrm{Na}_{2} \mathrm{SiO}_{3}-6$ г/л; 2 - електроліт $\mathrm{KOH}-2$ г/л $+\mathrm{Na}_{2} \mathrm{SiO}_{3}-6$ г/л; 3 - електроліт $\mathrm{KOH}-2$ г/л $+\mathrm{Na}_{2} \mathrm{SiO}_{3}-12$ г/л 


\section{MATEPIАЛОЗНАВСТВО № 3- 2020}

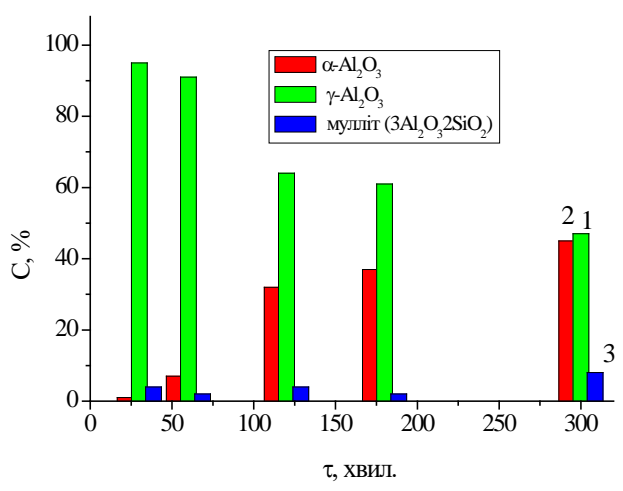

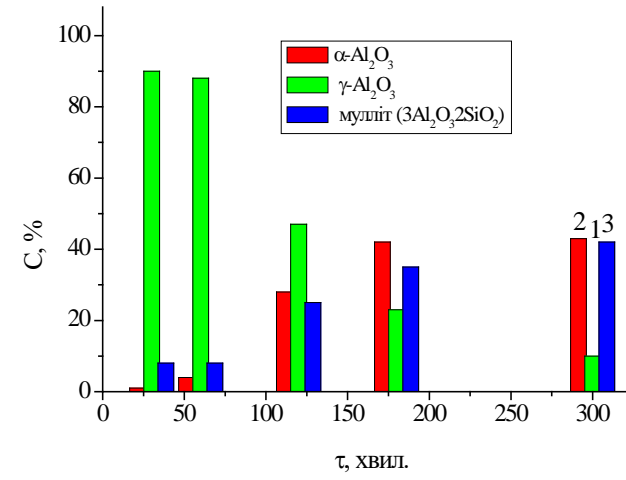

б

Рис 6. Залежність фазового складу від часу оксидування за електролізу в електролітах різних складів: а - КОН 2 г/л $+\mathrm{Na}_{2} \mathrm{SiO}_{3}-6$ г/л; б- $\mathrm{KOH}-2$ г/л $+\mathrm{Na}_{2} \mathrm{SiO}_{3}-12$ г/л, $1-\gamma-\mathrm{Al}_{2} \mathrm{O}_{3} ; 2-\alpha-\mathrm{Al}_{2} \mathrm{O}_{3} ; 3-$ муліт $\left(3 \mathrm{Al}_{2} \mathrm{O}_{3} \cdot 2 \mathrm{SiO}_{2}\right)$

за постійної щільності струму для різних електролітів. Видно, що за абсолютними значеннями прирощування не перевищує 15 мкм, проте характер зміни прирощування зі збільшенням часу процесу дещо відрізняється. Така відмінність проявляється у зменшенні кінетики прирощування для процесу в електроліті 3-го типу (рис. 5в, залежність 3) у разі тривалого оксидування. Напевно, зазначений ефект для оксидування в електроліті з найбільшим вмістом силікатної складової частини пов'язаний зі збільшенням водночас здатності розтравлювання електроліту під час оксидування.

Оскільки оксидування сплаву АК6 проводилося 3 метою створення зносостійкого покриття, то подальші результати вивчення фазово-структурних змін, морфології перетину покриття і вимірювання твердості відповідають базовому шару.

Результати рентгенодифрактометричних досліджень фазового складу покриттів, отриманих електролізом в електролітах 2-х складів (табл. 2), наведені на рисунку 6 (для електроліту складу $\mathrm{KOH} \mathrm{-} 1$ г/л + $\mathrm{Na}_{2} \mathrm{SiO}_{3}-6$ г/л, фазовий склад наведено на рис. 4 г).

Як видно 3 даних на рисунках 4 г і 6, фазовий склад МДО-покриттів, сформованих у лужно-силікатних електролітах, включає три основні фази: $\gamma-\mathrm{Al}_{2} \mathrm{O}_{3}$, $\alpha-\mathrm{Al}_{2} \mathrm{O}_{3}$ і муліт $\left(3 \mathrm{Al}_{2} \mathrm{O}_{3} \cdot 2 \mathrm{SiO}_{2}\right)$. Співвідношення фаз визначається режимом оксидування і тривалістю процесу. У разі малої тривалості процесу (до 120 хв) основною фазою в базовому шарі покриття $\epsilon \gamma-\mathrm{Al}_{2} \mathrm{O}_{3}$. Зі збільшенням тривалості процесу відбувається зміна фазового складу покриттів у результаті збільшення відносного вмісту $\alpha-\mathrm{Al}_{2} \mathrm{O}_{3}$ і появи мулітної фази. Водночас співвідношення фаз за тривалого оксидування залежить від складу електроліту. За малого вмісту лужної складової частини (електроліт 1 у таблиці 2) основною фазою покриття в разі тривалого оксидування стає фаза $\alpha-\mathrm{Al}_{2} \mathrm{O}_{3}$ (рис. 4г). За великого вмісту силікатної складової частини $\left(\mathrm{Na}_{2} \mathrm{SiO}_{3}\right)$ в електроліті (рис. 6) переважно формується муліт.

Універсальною характеристикою механічних властивостей оксидного покриття $є$ вимірювання

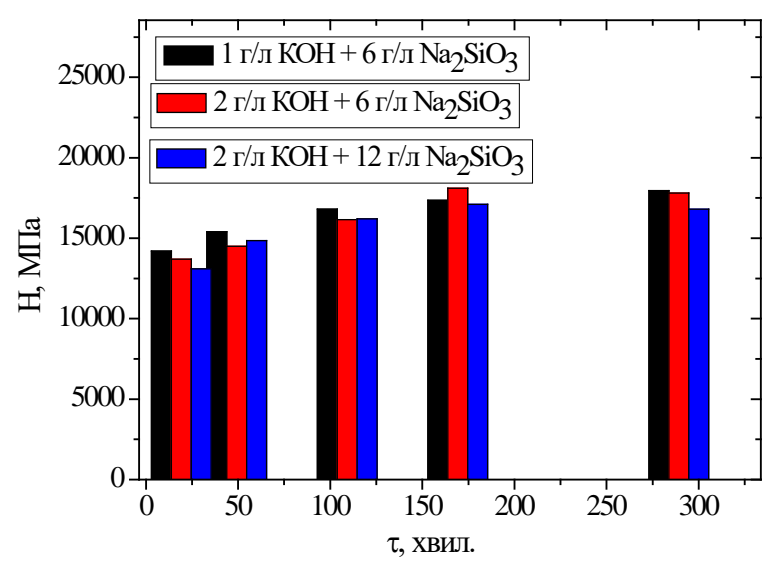

Рис. 7. Залежність твердості МДО-покриттів від тривалості процесу: 1 - електроліт 1 г/л КОН +6 г/л $\mathrm{Na}_{2} \mathrm{SiO}_{3}$; 2 - електроліт 2 г/л $\mathrm{KOH}+6$ г/л $\mathrm{Na}_{2} \mathrm{SiO}_{3} ; 3$ - електроліт 2 г/л $\mathrm{KOH}+12$ г/л $\mathrm{Na}_{2} \mathrm{SiO}_{3}$

мікротвердості. Отримані результати вимірювання мікротвердості покриттів, сформованих за щільності струму $\mathrm{j}=25 \mathrm{~A} /$ дм $^{2}$ у різних електролітах, наведені на рисунку 7.

Як видно з рисунка, зі збільшенням тривалості оксидування (отже, і товщини МДО-покриттів) твердість збільшується приблизно на $30 \%$ щодо первинно сформованого покриття (протягом 30 хв). Варто зазначити, що час 30 хв для порівняння обрано через те, що за меншого часу покриття має товщину приблизно 10-15 мкм, водночас досить велику неоднорідність поверхні, що призводить до непридатності його для використання в парах тертя.

У разі зіставлення твердості покриттів (рис. 7) з їхнім фазовим складом (рис. 4 і 6) виявляється кореляція підвищення твердості зі збільшенням відносного вмісту в покритті фази $\alpha-\mathrm{Al}_{2} \mathrm{O}_{3}$.

За середнього часового діапазону оксидування найбільша твердість досягається в електроліті складу 2 г/л $\mathrm{KOH}+6$ г/л $\mathrm{Na}_{2} \mathrm{SiO}_{3}$, у якому через найменшу 
швидкості зростання (рис. 5) висока потужність розряду дозволяє формувати фазу $\alpha-\mathrm{Al}_{2} \mathrm{O}_{3} 3$ вмістом, який перевищує 40\%. За найбільшого часу процесу найбільша твердість досягається в електроліті 1 г/л $\mathrm{KOH}+6$ г/л $\mathrm{Na}_{2} \mathrm{SiO}_{3}$. В електролітах із великим вмістом $\mathrm{Na}_{2} \mathrm{SiO}_{3}$, а також у разі використання технології 3 високою щільністю струму, збільшення відносного вмісту фази $\alpha-\mathrm{Al}_{2} \mathrm{O}_{3}$, імовірно, відбувається в результаті зміни процесу оксидування і переходу від мікродугових до дугових розрядів, у результаті чого не забезпечується найбільша твердість. Також водночас зростає і відносний вміст муліту (рис. 4), покриття формується більш пористе [4], що також призводить до зниження твердості покриття.

\section{ВИСНОВКИ}

1. Встановлено, що покриття, сформовані на сплаві АК6 у результаті мікродугового оксидування, мають двошарову структуру, які складаються 3 поверхневого технологічного шару і внутрішнього базового шару. Товщина технологічного шару становить $30-40 \%$ від товщини базового шару.

2. Основною фазою технологічного шару є фаза 3 відносно низькою твердістю - муліт $\left(3 \mathrm{Al}_{2} \mathrm{O}_{3} \cdot 2 \mathrm{SiO}_{2}\right)$. Основними фазами базового шару $є$ оксидні фази високої твердості $\gamma-\mathrm{Al}_{2} \mathrm{O}_{3} \mathrm{i} \alpha-\mathrm{Al}_{2} \mathrm{O}_{3}$ (корунд).

3. Визначено, що щільність струму впливає на швидкість зростання покриття і на фазовий склад у ньому. За низької щільності струму і малої тривалості процесу оксидування (до 30 хв) сплаву АК6 не забезпечується утворювання $\alpha-\mathrm{Al}_{2} \mathrm{O}_{3}$ фази, а основною фазою $є \gamma-\mathrm{Al}_{2} \mathrm{O}_{3}$. Це не дозволяє досягнути великої твердості покриття.

4. Збільшення щільності струму від 10 до $25 \mathrm{~A} /$ дм² $^{2}$ призводить до підвищення швидкості зростання покриття майже удвічі, водночас фазовий склад покриттів змінюється від двофазного на основі $\gamma-\mathrm{Al}_{2} \mathrm{O}_{3}$ і муліту на двофазний на основі фаз $\alpha-\mathrm{Al}_{2} \mathrm{O}_{3}$ i $\gamma-\mathrm{Al}_{2} \mathrm{O}_{3}$.

5. За великої щільності струму (40-60) А/дм² збільшення відносного вмісту фази $\alpha-\mathrm{Al}_{2} \mathrm{O}_{3}$ відбувається в результаті зміни процесу оксидування і переходу від мікродугових до дугових розрядів, у результаті чого також збільшується і відносний вміст муліту, а покриття формується більш пористе.

6. Склад лужно-силікатного електроліту впливає на швидкість зростання і фазовий склад: у разі збільшення вмісту силікатної $\left(\mathrm{Na}_{2} \mathrm{SiO}_{3}\right)$ складової частини в лужно-силікатному електроліті підвищується швидкість зростання покриття, проте фазовий склад збагачується мулітною фазою з невисокою твердістю.

7. Найбільш висока твердість 18200 МПа досягається в електроліті $\mathrm{KOH}-1$ г/л $+\mathrm{Na}_{2} \mathrm{SiO}_{3}-6$ г/л за максимальної тривалості процесу електролізу 300 хв, коли формується покриття товщиною базового шару приблизно 150 мкм із вмістом фази $\alpha-\mathrm{Al}_{2} \mathrm{O}_{3}$, яка досягає $87 \%$.

\section{REFERENCES}

[1] Cheng Y., Matykina E., Arrabal R., Skeldon P., Thompson G. E. (2012) Plasma electrolytic oxidation and corrosion protection of Zircaloy-4. Surface and coatings technology, vol. 206, iss. 14, pp. 3230-3239. URL: https://doi.org/10.1016/j. surfcoat.2012.01.011.

[2] Lesnevskiy L. N., Lyakhovetskiy M. A., Ivanova S. V., Nagovitsyna O. A. (2016) Structure and properties of surface layers formed on zirconium alloy by microarc oxidation. Journal of surface investigation: X-ray, synchrotron and neutron techniques, vol. 10, iss. 3, pp. 641-647. DOI: 10.1134/S1027451016030289.

[3] Chen J., Wang Z., Lu S. (2012) Effects of electric parameters on microstructure and properties of MAO coating fabricated on ZK60 Mg alloy in dual electrolyte. Rare metals, vol. 31, no. 2, pp. 172-177. DOI: 10.1007/s12598-012-0486-7.

[4] Clyne T. W., Troughton S. C. (2019) A review of recent work on discharge characteristics during plasma electrolytic oxidation of various metals. International materials reviews, vol. 64, iss. 3, pp. 127-162. https://doi.org/10.1080/09506608.2018.1466492.

[5] Cui S. H., Han J. M., Du Y. P., Li W. (2007) Corrosion resistance and wear resistance of plasma electrolytic oxidation coatings on metal matrix composites. Surface and coatings technology, vol. 201, iss. 9-11, pp. 5306-5309. https://doi.org/10.1016/j.surfcoat.2006.07.126.

[6] Subbotina V. V., Sobol' O. V., Belozerov, V. V., Makhatilova A. I., Shnay- der V. V. (2019) Use of the method of micro-arc plasma oxidation to increase the antifriction properties of the titanium alloy surface. Journal of nano- and electronic physics, vol. 11, no. 3., pp. 03025-01-03025-05. DOI: 10.21272/jnep.11(3).03025

[7] Martin J., Leone P., Nomine A., Veys-Renaux D., Henriona G., Belmonte T. (2015). Influence of electrolyte ageing on the plasma electrolytic oxidation of aluminium. Surface and coatings technology, vol. 269, pp. 36-46. https://doi.org/10.1016/j. surfcoat.2014.11.001.

[8] Jovović J., Stojadinović S., Šišović N. M., Konjević N. (2011) Spectroscopic characterization of plasma during electrolytic oxidation (PEO) of aluminium. Surface and coatings technology, vol. 206, pp. 24-28. https://doi.org/10.1016/j. surfcoat.2011.06.031.

[9] Abraimov N. V. Eliseev Yu. S., Kry'mov V. V. (1998) Aviaczionnoe materialovedenie i tekhnologiya obrabotki metallov [Aviation materials science and metal processing technology] : ucheb. posob. dlya aviacz. vuzov. M. : Vy'ssh. shk. 444 p. URL: https://www.twirpx.com/file/1148035/.

[10] Simchen F., Sieber M., Lampke T. (2017) Electrolyte influence on ignition of plasma electrolytic oxidation processes on light metals. Surface and coatings technology, vol. 315, pp. 205-213. https://doi.org/10.1016/j.surfcoat.2017.02.041.

[11] Ko Y. G., Namgung S., Shin D. H. (2010) Correlation between KOH concentration and surface properties of AZ91 magnesium alloy coated by plasma electrolytic oxidation. Surface and coatings technology, vol. 205, iss. 7, pp. $2525-2531$. https://doi.org/10.1016/j.surfcoat.2010.09.055. 
[12] Li H. X., Li W. J., Song R. G., Ji Z. (2012) Effects of different current densities on properties of MAO coatings embedded with and without $\alpha-\mathrm{Al}_{2} \mathrm{O}_{3}$ nanoadditives. Materials science and technology, vol. 28, iss. 5, pp. 565-568. https://doi.org/10.1179/1743284711Y.0000000084.

[13] Mota R. O. Liu Y., Mattos O. R., Skeldon P., Thompson G. E. (2008) Influences of ion migration and electric field on the layered anodic films on Al-Mg alloys. Corrosion science, vol. 50, iss. 5, pp. 1391-1396.

[14] Belozerov V., Mahatilova A., Sobol' O., Subbotina V., Subbotin A. (2017) Investigation of the influence of technological conditions of microarc oxidation of magnesium alloys on their structural state and mechanical properties. Eastern-european journal of enterprise technologies, vol. 2, iss. 5(86), p. 39-43. DOI: 10.15587/1729-4061.2017.96721.

[15] Belozerov V., Sobol O., Mahatilova A., Subbotina V., Tabaza T. A., Al-Qawabeha, U.F., Al-Qawabah S.M. (2017) The influence of the conditions of microplasma processing (microarc oxidation in anode-cathode regime) of aluminum alloys on their phase composition. Eastern-european journal of enterprise technologies, vol. 5, iss. 12-89, pp. 52-57. https://doi.org/10.15587/1729-4061.2017.112065.

[16] Sobol' O. V., Shovkoplyas O. A. (2013) On advantages of X-ray schemes with orthogonal diffraction vectors for studying the structural state of ion-plasma coatings. Technical physics letters, vol. 39(6), pp. 536-539. https://link.springer.com/content/ pdf/10.1134/S1063785013060126.pdf.

[17] Klopotov A. A., Abzaev Yu. A., Potekaev A. I., Volokitin O. G. (2012) Osnovy rentgenostrukturnogo analiza v materialovedenii [Fundamentals of X-ray structural analysis in materials science]. Tomsk : TGASU, 275 p. URL: https://www.twirpx.com/ file/1251095/.

\section{СПИСОК ВИКОРИСТАНОЇ ЛІТЕРАТУРИ}

[1] Plasma electrolytic oxidation and corrosion protection of Zircaloy-4 / Y. Cheng et al. Surface and coatings technology. 2012. Vol. 206. Iss. 14. P. 3230-3239. DOI: 10.1016/j.surfcoat.2012.01.011.

[2] Structure and properties of surface layers formed on zirconium alloy by microarc oxidation / L. Lesnevskiy et al. Journal of surface investigation: X-ray, synchrotron and neutron techniques. 2016. Vol. 10. Iss. 3. P. 641-647. DOI: 10.1134/ S1027451016030289.

[3] Chen J., Wang Z., Lu S. Effects of electric parameters on microstructure and properties of MAO coating fabricated on ZK60 Mg alloy in dual electrolyte. Rare metals. 2012. Vol. 31. № 2. P. 172-177. DOI: 10.1007/s12598-012-0486-7.

[4] Clyne T., Troughton S. A review of recent work on discharge characteristics during plasma electrolytic oxidation of various metals. International materials reviews. 2019. Vol. 64. Iss. 3. P. 127-162. DOI: 10.1080/09506608.2018.1466492.

[5] Corrosion resistance and wear resistance of plasma electrolytic oxidation coatings on metal matrix composites / S. Cui et al. Surface and coatings technology. 2007. Vol. 201. Iss. 9-11. P. 5306-5309. DOI: 10.1016/j.surfcoat.2006.07.126.

[6] Use of the method of micro-arc plasma oxidation to increase the antifriction properties of the titanium alloy surface V. Subbotina et al. Journal of nano- and electronic physics. 2019. Vol. 11. № 3. P. 03025-01-03025-05. DOI: 10.21272 jnep.11(3).03025.

[7] Influence of electrolyte ageing on the plasma electrolytic oxidation of aluminium / J. Martin et al. Surface and coatings technology. 2015. Vol. 269. P. 36-46. DOI: 10.1016/j.surfcoat.2014.11.001.

[8] Spectroscopic characterization of plasma during electrolytic oxidation (PEO) of aluminium / J. Jovović et al. Surface and coatings technology. 2011. Vol. 206. P. 24-28. DOI: 10.1016/j.surfcoat.2011.06.031.

[9] Абраимов Н., Елисеев Ю., Крымов В. Авиационное материаловедение и технология обработки металлов : учебное пособие для авиационных вузов. Москва : Высшая школа, 1998. 444 c. URL: https:/www.twirpx.com/file/1148035/.

[10] Simchen F., Sieber M., Lampke T. Electrolyte influence on ignition of plasma electrolytic oxidation processes on light metals. Surface and coatings technology. 2017. Vol. 315. P. 205-213. DOI: 10.1016/j.surfcoat.2017.02.041.

[11] Ko Y., Namgung S., Shin D. Correlation between KOH concentration and surface properties of AZ91 magnesium alloy coated by plasma electrolytic oxidation. Surface and coatings technology. 2010/ Vol. 205. Iss. 7. P. 2525-2531. DOI: 10.1016/j. surfcoat.2010.09.055.

[12] Effects of different current densities on properties of MAO coatings embedded with and without $\alpha$ - $\mathrm{Al}_{2} \mathrm{O}_{3}$ nanoadditives / H. X. Li et al. Materials science and technology. 2012. Vol. 28. Iss. 5. P. 565-568. DOI: 10.1179/1743284711Y.0000000084.

[13] Influences of ion migration and electric field on the layered anodic films on Al-Mg alloys / R. Mota et al. Corrosion science. 2008. Vol. 50. Iss. 5. P. 1391-1396.

[14] Investigation of the influence of technological conditions of microarc oxidation of magnesium alloys on their structural state and mechanical properties / V. Belozerov et al. Eastern-european journal of enterprise technologies. 2017. Vol. 2. Iss. 5 (86). P. 39-43. DOI: 10.15587/1729-4061.2017.96721.

[15] The influence of the conditions of microplasma processing (microarc oxidation in anode-cathode regime) of aluminum alloys on their phase composition / V. Belozerov et al. Eastern-european journal of enterprise technologies. 2017. Vol. 5. Iss. 12-89. P. 52-57. DOI: 10.15587/1729-4061.2017.112065.

[16] Sobol' O., Shovkoplyas O. On advantages of X-ray schemes with orthogonal diffraction vectors for studying the structural state of ion-plasma coatings. Technical physics letters. 2013. Vol. 39 (6). P. 536-539. URL: https://link.springer.com/content/ pdf/10.1134/S1063785013060126.pdf.

[17] Основы рентгеноструктурного анализа в материаловедении / А. Клопотов и др. Томск : ТГАСУ, 2012.275 с. URL: https://www.twirpx.com/file/1251095/. 